\title{
KOMUNIKASI ANTAR PRIBADI ORANG TUA DENGAN ANAK KETERBELAKANGAN MENTAL
}

\author{
Oleh : \\ SYISVA NURWITA \\ Dosen Prodi Ilmu Komunikasi Fakultas Ilmu Sosial UNIVED Bengkulu
}

\begin{abstract}
This research is entitled Interpersonal Communication of Parents with Children who Have Mental Retardation. In this research, the researcher wants to know how communication is used by parents with mental retardation. The aim of this research is to describe the interpersonal communication that is used in communicating with mentally retarded children. This research is a descriptive qualitative study using data collection technique that uses the technique of participant observation, in-depth interviews, and documentation. The result of this study shows that the interpersonal communication of parents with children who have mental retardation is interpersonal communication through verbal and nonverbal communication. The interpersonal communication is the most appropriate communication of parents of mentally retarded children because the interpersonal communication uses multiple stages, including contacts, involvement, and familiarity. The interpersonal communication is used for children with mental retardation can complete tasks the duties of the development of a normal child of his age.
\end{abstract}

Keywords: Interpersonal Communication, Parents and Children, Mental Retardation

\section{PENDAHULUAN}

Manusia diciptakan sebagai makhluk sosial, sebagai mahluk sosial tentu akan selalu berkomunikasi karena komunikasi memegang peranan penting bagi kelanggengan suatu hubungan, baik dalam ikatan teman, sahabat, kekasih ataukah hubungan terpenting di dunia, yaitu keluarga. Salah satu elemen dasar yang membuat kekokohan hubungan dalam keluarga adalah komunikasi. Komunikasi dapat dilakukan baik secara verbal maupun nonverbal. Komunikasi verbal dalam keluarga seperti saling mencurahkan isi hati, berpamitan untuk pergi ke sekolah, kantor, mengajak makan bersama, dan sebagainya. Sedangkan komunikasi secara nonverbal dalam keluarga dengan menggunakan gerak-gerik badan, menunjukkan sikap tertentu misalnya tersenyum, menggelengkan kepala dan mengangkat bahu. Komunikasi untuk menyampaikan 
informasi dan merupakan suatu aksi saling berbagi.

Dalam proses berkomunikasi terkadang seringkali komunikasi antara dua orang atau lebih tidak berjalan dengan baik karena mereka dapat saja menggunakan satu istilah atau kata yang sama, akan tetapi mempunyai arti yang berbeda atau menggunakan kata yang berbeda dengan arti yang sama. Komunikasi yang paling sering dilakukan sejak manusia dilahirkan yaitu dalam kehidupan keluarga, keluarga merupakan bagian terpenting dalam kehidupan manusia, yang terdiri dari seorang ayah, ibu, dan anak. Dalam membina rumah tangga umumnya pasangan suami istri menginginkan kehadiran seorang anak dimana anak akan mendatangkan suatu perubahan baru dalam keluarga dan mempererat tali cinta pasangan suami istri. Bagi orang tua anak merupakan titipan Tuhan yang harus dijaga dan dipelihara dengan sebaik-baiknya. Setiap orang tua mengharapkan anaknya tumbuh dan berkembang dengan sempurna, baik secara fisik maupun psikologis.

Tujuan komunikasi dalam interaksi keluarga ditinjau dari kepentingan orang tua adalah untuk memberikan informasi, nasehat, mendidik dan menyenangkan anakanak. Anak berkomunikasi dengan orang tua adalah untuk mendapatkan saran, nasehat, masukan atau dalam memberikan respon dari pertanyaan orang tua. Komunikasi antar anggota keluarga dilakukan untuk terjadinya keharmonisan dalam keluarga. Komunikasi dapat mencapai aspek kognitif menyangkut kesadaran dan pengetahuan, aspek afektif menyangkut sikap dan perasaan dan aspek psikomotorik menyangkut perilaku dan tindakan. Komunikasi di antara anggota keluarga yaitu terjadinya perubahan perilaku anggota keluarga dalam menjaga keharmonisan hubungan keluarga. Komunikasi yang terjadi dalam keluarga merupakan komunikasi yang unik, melibatkan paling sedikit dua orang yang mempunyai sifat, nilai-nilai, pendapat, sikap, pikiran dan perilaku yang khas dan berbedabeda (Nina Suyati.2009:24).

Komunikasi keluarga tidak sama dengan komunikasi antar anggota kelompok biasa. Komunikasi yang terjadi dalam suatu keluarga tidak sama dengan komunikasi keluarga yang lain. Setiap keluarga mempunyai komunikasi tersendiri. Relasi antara anak dan orang tua menunjukkan adanya keragaman yang luas. Relasi orang tua dan anak dipengaruhi dan ditentukan oleh sikap orang tua. Sikap yang berhubungan dengan afeksi dan dominasi; ada orang tua yang mendominasi, yang memanjakan, acuh tak acuk dan orang tua akrab, terbuka, bersahabat. Sikap orang tua yang berhubungan dengan ambisi dan minat yaitu sikap orang tua yang mengutamakan sukses sosial, milik keduniawian, suasana keagamaan dan nilai-nilai artistik.

Komunikasi keluarga erat kaitannya dengan dengan konsep diri anak. Minimnya komunikasi dalam keluarga berdampak pada rendahnya konsep diri anak atau cenderung ke arah negatif (Nina Suyati.2009.25). Sejak dini, anak harus sudah ditanamkan konsep diri melalui komunikasi yang efektif dan positif dari keluarga. Karena, setelah 
melewati komunikasi keluarga, komunikasi anak akan menuju komunikasi yang lebih luas, yaitu komunikasi kelompok, rekan kerja, organisasi, dan sebagainya. Dan dari sanalah akan terlihat seberapa tinggi tingkat komunikasi keluarga yang telah dibina.

Bagi anak yang memiliki keterbelakangan mental sangat susah untuk berkomunikasi kepada orangorang disekitar sehingga menghambat perkembangan anak secara psikis maupun biologis. Ditambah lagi dengan ketidak pahaman orang tua dalam melakukan komunikasi dengan anak yang mengalami keterbelakangan mental misalnya anak yang mengalami keterbelakangan mental banyak orang tua menggunakan komunikasi seperti pada umumnya, padahal anak-anak ini membutuhkan perhatian khusus dan komunikasi dengan cara yang berbeda dari anakanak normal lainnya, ketidak pahaman orang tua serta kesibukan orang tua membuat anak yang mengalami keterbelakangan mental menjadi semakin mengalami penurunan dalam proses komunikasi dan perkembangannya. Dalam penelitian ini peneliti akan meneliti bentuk komunikasi orang tua yang memiliki anak keterbelakangan mental. Dalam komunikasi keseharian atau sehari-hari orang tua biasanya berkomunikasi seperti berkomunikasi dengan anak-anak normal pada umumnya, padahal anak keterbelakangan mental merupakan anak yang dikategorikan anak berkebutuhan khusus misalnya dalam hal komunikasi harusnya menggunakan komunikasi yang dapat ia pahami sesuai dengan kondisi. Dalam berkomunikas orang tua belum memahami kondisi sehingga ketika berkomunikasi sering terjadi kesalahan. Melihat fenomena ini peneliti merasa tertarik untuk melakukan penelitian terhadap orang tua tentang komunikasi orang tua dengan anak yang mengalami keterbelakangan mental. Berdasarkan latar belakang diatas maka peneliti tertarik untuk meneliti tentang "Komunikasi Antar Pribadi Orang Tua dengan Anak yang Mengalami Keterbelakangan Mental. Dari uraian latar belakang di atas, maka peneliti dapat merumuskan Bagaimana komunikasi antar pribadi orang tua dengan anak yang mengalami keterbelakangan mental. Secara umum tujuan penelitian ini bertujuan untuk mendeskripsika komunikasi antar pribadi yang digunakan orang tua dengan anak yang mengalami keterbelakangan mental.

\section{METODE PENELITIAN}

Tipe penelitian yang
digunakan dalam penelitian ini adalah penelitian yang disajikan secara deskritif kualitatif. Menurut Sugiyono (2012:7-8) Penelitian kualitatif adalah penelitian tentang riset yang bersifat deskriptif dan cenderung menggunakan. Teknik Pengumpulan Data Observasi Partisipan menurut Suharsimi (2010: 199-200) Obrservasi merupakan salah satu teknik pengumpulan data yang tidak hanya mengukur sikap dari responden (wawancara) namun juga dapat digunakan untuk merekam berbagai fenomena yang terjadi (situasi, kondisi). Wawancara adalah sebuah dialog yang dilakukan oleh pewawancara (interviewer) 
untuk memperoleh informasi dari terwawancara. Wawancara merupakan teknik pengumpulan data yang dilakukan melalui tatap muka dan tanya jawab langsung antara pengumpul data maupun peneliti terhadap nara sumber atau sumber data. (Suharsono Arikunto 2010: 198). Dokumentasi Menurut Moleong (2002:161) merupakan bahan tertulis digunakan untuk keperluan peneliti karena alasanalasan yang dapat dipertanggung jawabkan seperti sumber data yang stabil, kaya dan berguna sebagai bukti. Teknik Analisis Data menurut Patton dalam Moleong adalah "Proses mengatur urutan data, mengorgamsasikan kedalam suatu pola, ketegori dan satuan uraian dasar". Menurut Moleong (2011:162) langkah-langkah atau proses analisis data secara umum dapat digunakan sebagai berikut: "Proses analisis data dimulai dengan menelaah seluruh data yang tersedia dan berbagai sumber yaitu dari hasil wawancara, pengamatan yang sudah dituliskn dalam catatan lapangan, dokumentasi pribadi, dokumntasi resmi, gambar, foto-foto dan sebagainya. Setelah dibaca, dipelajari dan ditelaah maka langkah berikutnya adalah mengadakan reduksi data yang dilakukan dengan jalan membuat abstrak. Abstraksi merupakan usaha membuat rangkuman yang inti, proses dan pernyataan-pernyataan yang perlu dijaga sehingga tetap berada didalamnya langkah selanjutnya adalah menyusunnya dalam satuansatuan kemudian dikatagorikan pada langkah berikutnya. Kategorikategori ini dilakukan sambil membuat koding. Tahap akhir dari analisis ini adalah pemeriksaan keabsahan data, setelah selesai tahap ini, mulailah tahap penfsiran data dalam mengelola hasil sementara menjadi teori substantive dengan menggunakan beberapa metode tertentu.

\section{HASIL PENELITIAN DAN PEMBAHASAN}

\section{Tahap dalam Komunikasi Antar Pribadi}

Ada lima tahap dalam komunikasi antar pribadi, yaitu:

\section{Kontak}

Tahap pertama kita melakukan kontak. Seperti bersinggungan masalah fisik. Ada beberapa macam persepsi alat indera seperti melihat, mendengar, merasa, mencium, dan sebagainya. Dari hasil penelitian yang peneliti lakukan terhadap orang tua anak yang mengalami keterbelakangan mental, mereka mengatakan bahwa sebagai orang tua mereka dapat melihat kondisi anak mereka yang mengalami keterbelakangan mental, dapat merasakan apa yang anak mereka rasakan namun sulit untuk mendengar apa yang disampaikan oleh anaknya karena untuk berbicara anak masih terbatah-batah dan susunan kata kurang jelas. Dari hasil penelitian atas dapat digambarkan bahwa salah satu tahapan komunikasi antar pribadi antara orang tua dengan anak pada tahap kontak sudah dapat dilaksanakan hanya saja orang tua yang memiliki anak keterbelakangan mental belum dapat merealisasikannya dengan sebagaimana mestinya hal ini 
dikarenakan salah satu nya adalah keterbatasan waktu.

\section{Keterlibatan}

Keluarga tentu memiliki hubungan pada setiap anggota keluarganya. Hubungan tersebut membuat antara anggota keluarga yang satu dengan yang lain memiliki keterlibatan yang sangat erat. Hal ini juga berlaku pada keluarga yang memiliki anak keterbelakangan mental, meskipun ada salah satu anggota keluarga yang memiliki kekurangan tetap saja mereka memiliki keterlibatan didalamnya. Tahap ini biasanya tahap pengenalan lebih jauh, ketika kita ingin mengikatkan diri kita untuk mengenal orang lain dan juga mengungkapkan diri kita. Dari hasil wawancara diatas dapat penulis pahami bahwa keterlibatan orang tua dalam kegiatan anak sangatlah penting apalagi dalam sebuah keluarga yang di dalam keluarga itu sendiri memiliki anak keterbelakangan mental

\section{Keakraban}

Pada tahap anda mengikat diri anda dengan orang lain lebih jauh. Anda memungkinkan membina hubungan primer dimana orang lain menjadi sahabat baik atau kekasih anda. Komitmen ini bisa membantu orang tersebut secara moril atau matril.

\section{Perusakan}

Tahap ini merupakan penurunan hubungan, ketika ikatan diantara kedua pihak melemah. Pada tahap ini anda mungkin merasa bahwa hubungan ini mungkin tidaklah sepenting yang anda pikirkan sebelumnya.

Keluarga yang memiliki anggota keluarga yang mengalami keterbelakangan mental biasanya akan merasa bahwa keluarga mereka cacat sekeluarga tapi mereka tidak perna merusak hubungan dalam keluarganya. Dari hasil penelitian diatas dapat dikatakan bahwa walaupun anggota keluarga mereka ada yang mengalami keterbelakangan mental namun rasa saling menyayanginya sangatlah kuat, sehingga dalam tahap ini keluarga yang menjadi informan penelitian tidak melewati tahap perusakan hubungan.

\section{PENUTUP}

\section{Kesimpulan}

Berdasarkan hasil penelitian dan pembahasan tentang model komunikasi orang tua dengan anak yang mengalami keterbelakangan mental dapat disimpulkan bahwa komunikasi antar pribadi yang digunakan orang tua adalah komunikasi antar pribadi dengan berkomunikasi secara verbal dan non verbal. Dari hasil penelitian yang dilakukan dapat dipahami bahwa anak yang mengalami keterbelakangan mental lebih memahami komunikasi yang disampaikan oleh orang tua. Pada komunikasi antar pribadi orang tua dengan anak melewati beberapa tahap diantaranya kontak, keterlibatan, keakraban. Melalui tahap tersebut anak yang mengalami keterbelakangan mental dapat memahami pesan-pesan apa saja yang diberikan oleh lingkungan sekitarnya, dan melalui komunikasi antar pribadi dengan orang tua anak dapat secara perlahan menyelesaikan tugas-tugas perkembangannya. 


\section{Saran}

Dari hasil penelitian peneliti dapat memberikan beberapa masukan atau saran kepada orang tua yang mengalami anak keterbelakangan mental diantaranya:

1. Bagi orang tua yang memiliki anak keterbelakangan mental agar dapat lebih memperhatikan tugas perkembangan apa saja yang harus diselesaikan oleh anak seusia anak keterbelakangan mental tersebut

2. Agar orang tua dapat memahami dan mengetahui cara dalam membantu anak yang mengalami keterbelakangan mental dalam berkomunikasi dengan lingkungan.

3. Bagi anggota keluarga yang memiliki anggota keluarga keterbelakangan mental agar dapat membantu dan saling mendukung.

4. Bagi lingkungan agar dapat memahami kondisi anak keterbelakangan mental.

\section{DAFTAR PUSTAKA}

Alma, Buchari. 2008. "Belajar Mudah Penelitian". Bandung, Alfabeta

Arikunto, Suharsimi. 2010."Prosedu Penelitian Suatu Pendekatan P raktik”. Jakarta, Rineka Cipta

Budyatna, Muhammad. 2011.'Teori Komunikasi Antar pribadi". Jakarta, Kencana

Devito, Joseph. 2011."Komunikasi Antarmanusia". Tangerang, Karisma
Devito A. Joseph. 2011." Komunikasi Antar Manusia". Tangerang, Karisma

Halgin Richard. 2010." Psikologi Abnormal Perspektif Klinis pada Gangguan Psikologis". Jakarta, Salemba Humanika

Hurlock, Elizabeth.1990."Psikologi Perkembangan Suatu Pendekatan Sepanjang Rentang Kehidupan". Jakarta, Erlangga

Nevid, Jeffrey. 2003."Psikologi Abnormal'. Jakarta, Erlangga

Nevid Jeffrey. 2005." Psikologi Abnormal". Jakarta, Erlangga

Miller. 1990. "Komunikasi Manusia". Jakarta, Rineka Cipta

Riswadi. 2013."Psikologi Komunikasi”. Yogyakarta, Graha Ilmu

Soemirat, Soleh. 2005. "Dasar-dasar Publik Relations". Bandung, PT.Remaja Rosdakarya

Sutton Johnson.2001."Public Relations". Bandung, PT. Remaja Rosdakarya

Suwandi, Basrowi. 2008." Penelitian Kualitatif”. Jakarta, Rineka Cipta

Widjaja. 2010."Komunikasi, Komunikasi dan Hubungan Masyarakat". Jakarta, Bumi Aksara

Morissan. 2013."Psikologi Komunikasi". Bogor, Ghalia Indonesia 